\title{
Implementasi Kendali Tegangan Output Buck Converter Berbasis Simulink Matlab
}

\author{
Ari Anggawan 1 , Muldi Yuhendri² \\ 1,2 Jurusan Teknik Elektro, Fakultas Teknik, Universitas Negeri Padang \\ Jl. Prof. Dr. Hamka, Air Tawar Padang, 35132, Indonesia \\ arianggawan12@gmail.com ${ }^{1}$, muldiy@ft.unp.ac.id ${ }^{2}$
}

\begin{abstract}
The rapid development of technology to date has made many electrical and electronic equipment that require a direct current (dc) voltage source whose output voltage can be adjusted to the needs of the user. There are several direct voltage levels that are commonly used by electrical and electronic equipment. To get a direct voltage that can be used for various equipment, a direct voltage source is needed which can be automatically varied according to need is required. One way to convert a dc voltage source to a lower dc voltage source is by using a buck converter circuit. This study designed a buck type direct current converter is porposed to use the Arduino uno as a PWM signal generator circuit to control to control the 24 volt input voltage. The converter output voltage regulation is implemented through a potentiometer and Arduino programming using the simulink Matlab. In this research, a buck converter is tested with output voltage feedback so that the output voltage remains stable. The result of the test that have been carried out show that the buck converter designed in this study has worked well in accordance with objectives. This can be seen from the buck converter output voltage that is in accordance with the reference voltage using a potentiometer that is included in the simulink Matlab program.
\end{abstract}

Keywords-Buck converter, dc voltage, arduino, matlab simulink.

Abstrak-Pesatnya perkembangan teknologi sampai saat ini membuat banyak perlatan listrik maupun elektronik yang membutuhkan sumber tegangan searah atau direct current (dc) yang tegangan keluarannya dapat disesuaikan dengan kebutuhan pemakai. Ada beberapa level tegangan searah yang umum digunakan oleh peralatan listrik maupun elektronik. Untuk mendapatkan tegangan searah yang bisa dipakai untuk bebagai peralatan, maka dibutuhkan sumber tegangan searah yang secara otomatis dapat divariasikan sesuai dengan kebutuhan. Untuk mengkonversikan sumber tegangan dc ke sumber tegangan dc yang lebih rendah salah satu caranya yaitu dengan menggunakan rangkaian konverter buck. Penelitian ini merancang konveter arus searah tipe buck yang dapat menurunkan tegangan searah dengan output yang bervariasi. Konverter buck dirancang menggunakan Arduino uno sebagai rangkaian pembangkit sinyal PWM untuk mengendalikan tegangan input 24 volt. Pengaturan tegangan output konverter di terapkan melalui sebuah potensiometer serta pemograman Arduino menggunakan simulink Matlab. Pada penelitian ini dilakukan pengujian konverter buck dengan umpan balik tegangan keluaran agar tegangan keluaran tetap stabil. Hasil pengujian yang sudah dilakukan menunjukan bahwa konverter buck yang dirancang dalam penelitian ini telah bekerja dengan baik sesuai dengan tujuan. Hal ini dapat dilihat dari tegangan output konverter buck yang telah sesuai dengan tengangan referensi menggunakan potensiometer yang dimasukkan dalam program simulink Matlab.

Kata kunci- Konverter buck, tegangan dc, arduino uno, simulink matlab.

\section{Pendahuluan}

Sumber energi yang banyak digunakan dalam peralatan sehari-hari yaitu energi listrik. Mulai dari skala kecil seperti untuk kebutuhan rumah tangga hingga kebutuhan skala besar sebagai sumber energi bagi industri. Pembangkit-pembangkit tenaga listrik yang menghasilkan energi listrik pun harus sesuai dengan standar kelistrikan yang dibutuhkan beban. Standar tegangan dan frekuensi merupakan bagian yang harus diperhatikan. Untuk standar tegangan, ada dua jenis tegangan yang biasa digunakan untuk berbagai keperluan, yaitu tegangan bolak-balik atau disebut juga dengan alternating current (ac) dan tegangan searah atau direct current (dc)[1].
Dalam bidang elektronika daya telah banyak teknologi yang berkembang untuk menghasilkan ketersediaan suplai tegangan searah (dc), dimana keluaran dari tegangan searah (dc) ini bisa diubah-ubah menjadi lebih kecil dan lebih besar. Proses konversi tegangan searah ini dikenal sebagai DC Chopper [2]-[3]. Pada pengaplikasianya sebuah sumber penghasil tegangan searah seperti baterai dan panel surya dapat dirubah keluaranya menjadi lebih kecil atau lebih besar dengan sebuah DC Chopper agar dapat dimanfaatkan untuk berbagai perangkat elektronika sesuai keperluan[4].

Sesuai dengan tegangan keluaran yang dihasilkan, konverter dc-dc bisa dibagi atas konverter buck untuk memperoleh tegangan yang lebih kecil dari tegangan masukkan, konverter boost untuk memperoleh tegangan keluaran yang lebih besar dari tegangan masukkan dan 
konverter buck-boost yang mampu menaikkan dan menurunkan tegangan sehingga tegangan keluarannya bisa lebih kecil dan lebih besar dari tegangan masukkan [5]-[6]. Pada konverter dc-dc ini terdapat dua komponen filter yaitu induktor dan kapasitor yang bertugas memperhalus tegangan dan arus keluaran[7].

Penelitian tentang penggunaan DC Chopper jenis buck telah dilakukan beberapa peneliti, seperti pada penelitian sistem penyimpanan energi listrik ke baterai menggunakan rangkaian buck konverter yang menggunakan Arduino sebagai kontroler dengan metode pulse Width Modulation (PWM)[8], untuk menurunkan dan menstabilkan tegangan sebesar 14,4 Volt sehingga tidak melewati ambang batas pengisian baterai yaitu 14,4 - 15 VDC untuk mejaga baterai agar tidak cepat rusak.

Pada penelitian ini dirancang konverter buck untuk menghasilkan tegangan keluaran dc yang bervariasi dengan tegangan masukkan dc 24 volt. Konverter buck dirancang untuk menghasilkan tegangan yang lebih kecil dari tengangan masukkan. Tegangan keluarannya yaitu berkisar antrara 6 - 18 Volt, diamana tegangan keluaran konverter buck ini dapat dimanfaatkan sebagai sumber tegangan peralatan elektronik maupun mesin listrik.

Nilai duty cycle pulsa modulasi (PWM) sakelar daya konverter menetukan tegangan keluaran konverter buck. Agar tegangan keluaran yang hasilkan sesuai dengan keinginan, maka duty cycle ini harus diatur[9][10]. Pada penelitian ini, pengaturan tegangan keluran konverter buck dirancang menggunakan metode penguatan proporsional. Penerapan dari metode kontrol ini membutuhkan perangkat mikrokontroler. Beberapa mikrokontroler yang telah diterapkan untuk konverter buck antara lain miktokontroller Atmega[11] dan Arduino[12]-[13]. Mikrokontroler yang digunakan untuk konverter buck dalam penelitian adalah board arduino uno. Pemilihan mikrokontroler ini dikarenakan penggunaannya lebih mudah. Biasanya arduino ini diprogram dengan software Arduino Integrated Developtment Enviroenment (IDE). Arduino pada penelitian ini diprogram dengan software simulink Matlab. simulink Matlab dipilih karena lebih mudah digunakan untuk mendesain sistem kendali.

\section{Metode}

Penelitian ini merancang implementasi konverter buck untuk mendapatkan tegangan dc yang bervariasi. Konverter buck dirancang dengan tegangan input 24 volt dan tegangan output antara 6-18 volt. Kendali tegangan output konverter buck dirancang menggunakan metode penguatan proporsional yang di implementasikan dengan Arduino yang di program dengan software simulink Matlab. Rancangan konverter buck yang diusulkan dalam penelitian ini dijabarkan menggunakan blok diagram.

\section{Blok Diagram}

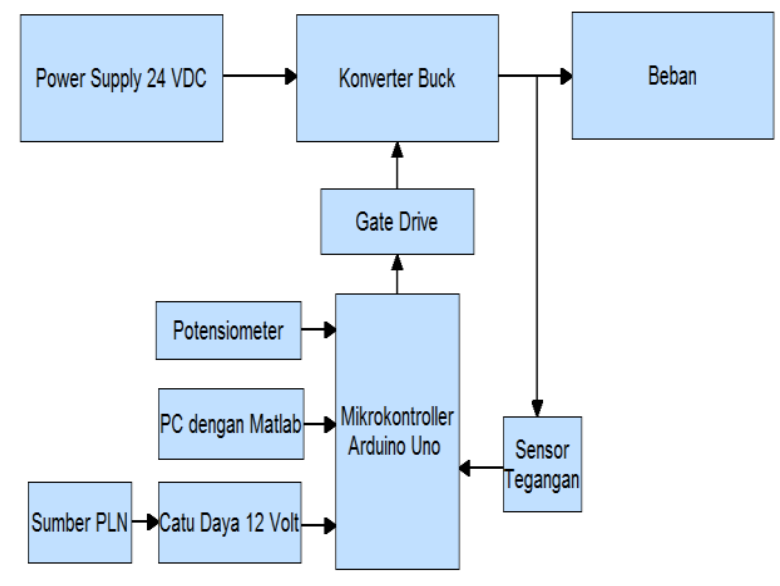

Gambar 1. Blok diagram

Dari blok diagram pada gambar 1 dapat dilihat bahwa catu daya yang digunakan sebagai penyearah 12 VDC mendapatkan sumber tegangan 220 VAC dari PLN. Tegangan 12 VDC yang dihasilkan catu daya disuplai ke rangkaian gate drive dan juga sebagai sumber tegangan mikrokontroler Arduino uno. Mikrokontroler Arduino sebagai pusat kendali menerima input dari potensiometer yang digunakan sebagai masukkan tegangan output referensi, dan input dari sensor tegangan untuk mengukur tegangan keluaran konverter buck yang digunakan Arduino sebagai feedback kendali tegangan ardunio. Gate driver digunakan sebagai switching mosfet pada rangkaian konverter buck dimana gate driver mendapatkan sinyal Pulsa PWM yang dari mikrokontroler Arduino. Rangkaian konverter buck bekerja menurunkan tegangan 24 VDC yang dari tegangan input power supply DC, dimana tegangan output buck tersebut diberi beban sebuah resistor dengan nilai $45 \mathrm{ohm}$.

Tegangan output Konverter buck ditentukan oleh nilai waktu switching dari sakelar daya konverter buck, waktu switching saklar daya ini diatur dengan metode pulse width modulation (PWM). Waktu switching sakelar pada PWM ini ditentukan oleh lebar pulsa modulasi, dimana lebar pulsa tersebut ditentukan oleh duty cycle [14]. Sakelar daya yang digunakan konverter buck adalah mosfet. Gambar 2 menunjukan skema konverter buck yang dirancang,

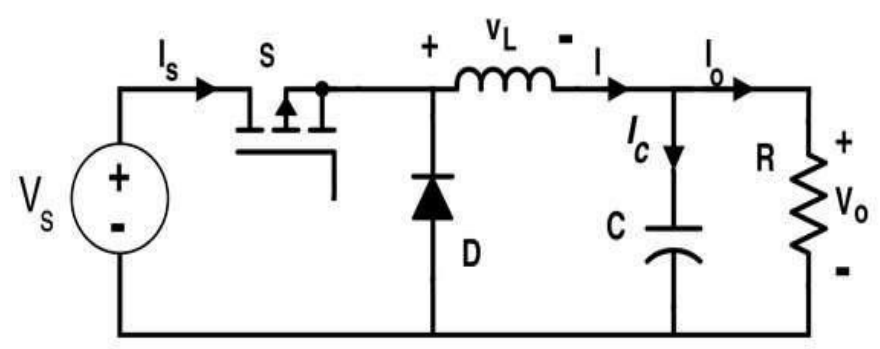

Gambar 2. skema rangkaian konverter buck[15] 
Gambar 2 menunjukan skema rangkaian konverter buck yang terdiri dari mosfet, diode, induktor dan kapasitor, konverter buck bekerja berdasarkan konsep pengisian dan pengosongan induktor dan kapasitor pada rangkaian tersebut. Pengisian dan pengosongan kedua komponen tersebut ditentukan oleh waktu switching dari sakelar daya dimana waktu switching ini ditentukan oleh duty cycle, Hubungan tegangan output converter buck dengan duty cycle ditunjukkan dengan rumus:

$$
V_{\text {out }}=V_{\text {in }} \cdot D
$$

Dimana D merupakan duty cycle sedangkan Vout dan Vin merupakan tegangan output dan tengan input konverter. Pada persamaan (1) di tunjukkan bahwa tegangan output konverter buck berbanding lurus dengan nilai duty cycle. peningkatan nilai duty cycle yang diberikan membuat tegangan yang dikeluarkan semakin besar. Duty cycle ini yang akan memodulasi sakelar daya konverter.

\section{Perancangan Hardware}

Perancangan hardware merupakan bagian yang sangat penting dalam pembuatan konverter buck ini, karena merupakan suatu tahapan dalam pembuatan alat. Agar saat proses pengerjaan tingkat kesalahan dapat dikurangi dan mempermudah dalam proses pembuatan alat tersebut. Dengan adanya perancangan hardware ini barulah kinerja sistem dapat diuji secara nyata.

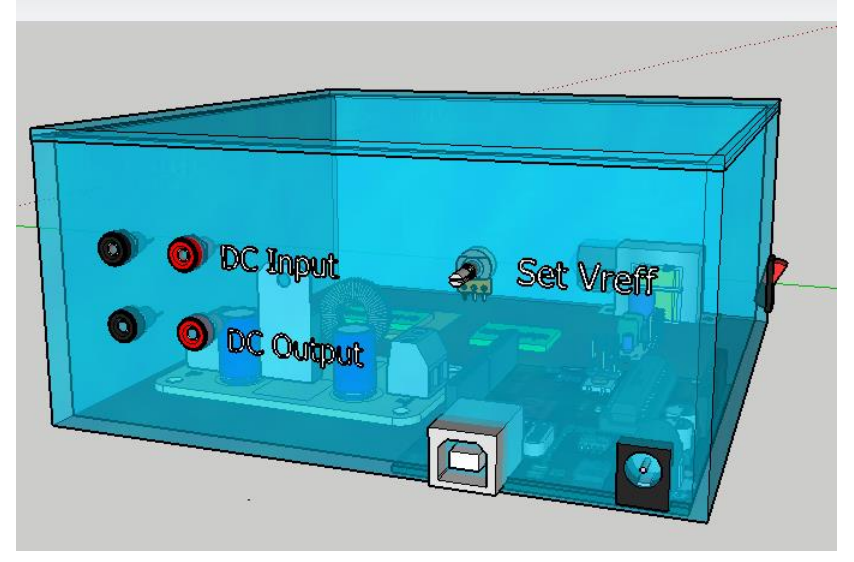

Gambar 3. Rancangan hardware

Gambar 3 memperlihatkan hardware rangkaian konverter buck yang dibuat pada penelitian ini. Disisi depat terdapat dua pasang port sebagai terminal DC input dan output, serta sebuah potensiometer yang digunakan sebagai setting tegangan ouput referensi dan terdapat port usc jack yang digunakan untuk transfer data dari komputer ke Arduino dan sebaliknya.

\section{Perancangan Software}

Untuk mendapatkan pulsa PWM konverter buck yang sesuai dengan tegangan output yang diinginkan, maka dilakukan proses pemograman Arduino dengan simulink
Matlab dengan alur yang ditunjukkan oleh diagram alir pada gambar 4. Pemograman Arduino dengan simulink Matlab dimulai dengan inisialisasi port input dan output Arduino pada Simulink. Selanjutnya dilakukan pembuatan blok-blok program, seperti blok Analog input untuk untuk memasukkan nilai tegangan output referensi yang diinginkan, blok lookup table untuk mengkonversikan nilai duty cycle. Blok saturation untuk membatasi nilai duty cycle yang diizinkan, blok output PWM untuk mengkonversikan nilai duty cycle menjadi pulsa PWM dan blok scope untuk menampilkan grafik tegangan referensi dan tegangan output yang terbaca oleh sensor tegangan. Blok output PWM berisikan nomor pin PWM Arduino yang digunakan serta frekuensi switching dari PWM. Frekuensi switching yang digunakan untuk modulasi sakelar daya konverter dirancang sebesar $31 \mathrm{kHz}$, sedangkan pin PWM yang digunakan adalah pin 9. Pin 9 ini kemudian dihubungkan dengan rangkaian driver gate, seperti yang ditunjukkan pada gambar 4 .

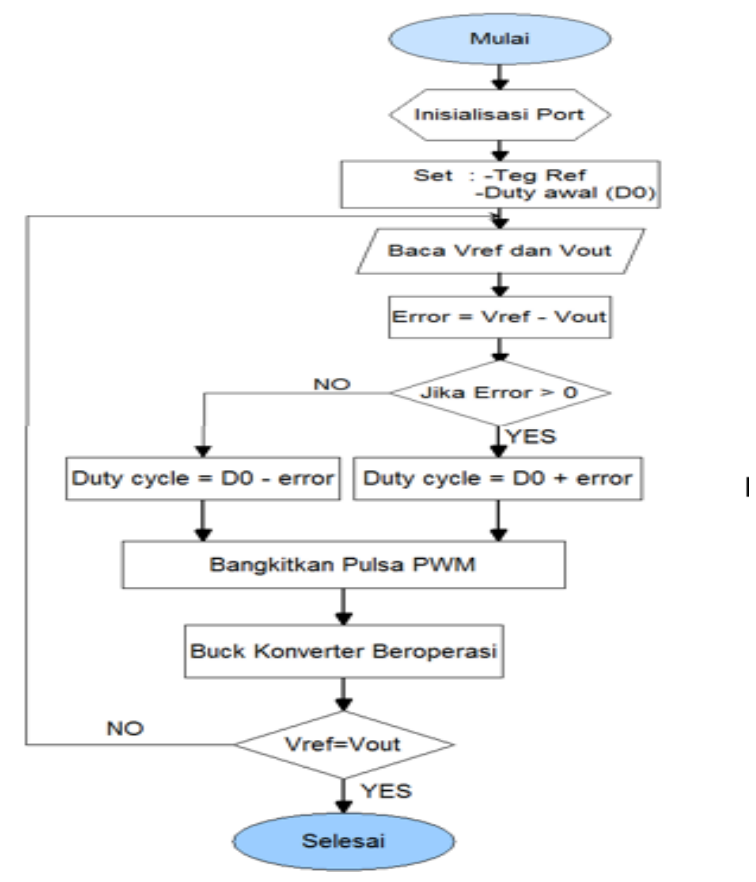

Gambar 4. Diagram alir pemograman Arduino

\section{HASIL DAN PEMBAHASAN}

Setelah selesai membuat program Arduino menggunakan simulink, selanjutnya dilakukan pengujian alat. Dalam pengujian ini, konverter dihubungkan dengan beban resistor. Untuk melihat grafik tegangan input dan pwm Arduino digunakan osiloskop digital, sedangkan untuk melihat grafik tegangan output dan tegangan referensi digunakan blok scope yang ada dalam Simulink Matlab. 


\section{Rangkaian Keseluruhan}

Rangkaian keseluruhan adalah suatu perancangnan komponen elektronik, dengan adanya penjelasan dari diagram blok yang dapat memberikan kemudahan dalam mengetehaui prinsip kerja dari alat secara keseluruhan, dan juga sebegai petunjuk dalam menganalisa jika terjadi kesalahan pada alat secara keseluruhan

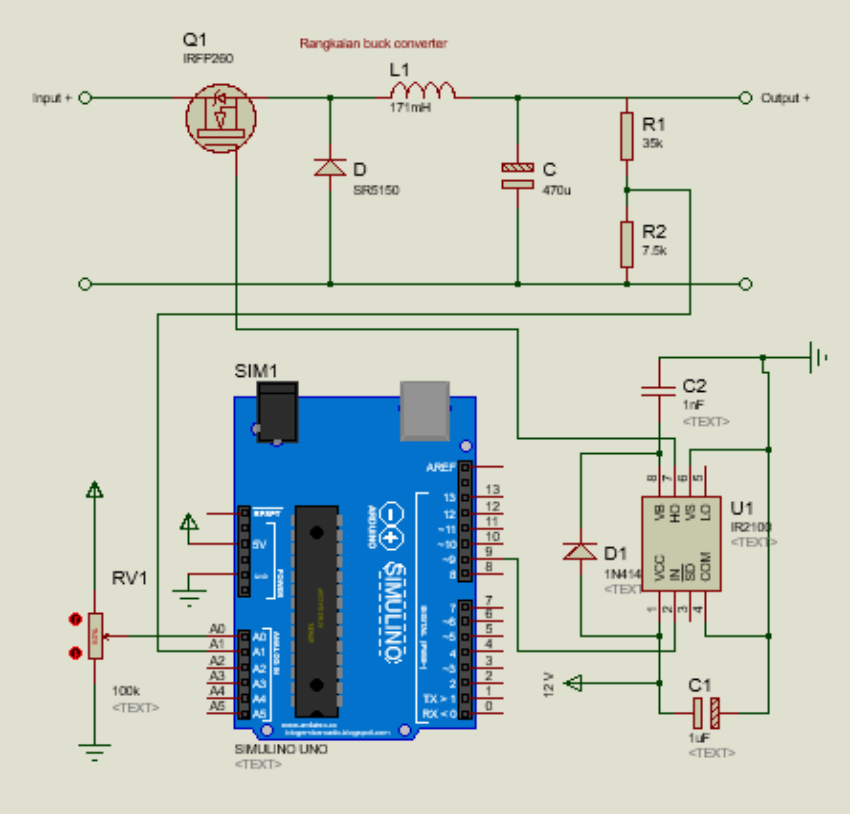

Gambar 5. skema rangkaian konverter buck dengan Arduino

Dalam penelitian ini, pulsa PWM dibangkitkan melalui pin PWM Arduino uno yang di program dengan menggunakan software simulink Matlab. Pin PWM Arduino ini dihubungkan dengan rangkaian driver gate yang berfungsi menaikkan level tegangan output pin PWM aduino sesuai denga tegangan yang dibutuhkan pin gate Mosfet. Gambar 5 menunjukan skema rangkaian konverter buck yang terhubung dengan mikrokontroller Arduino Uno.

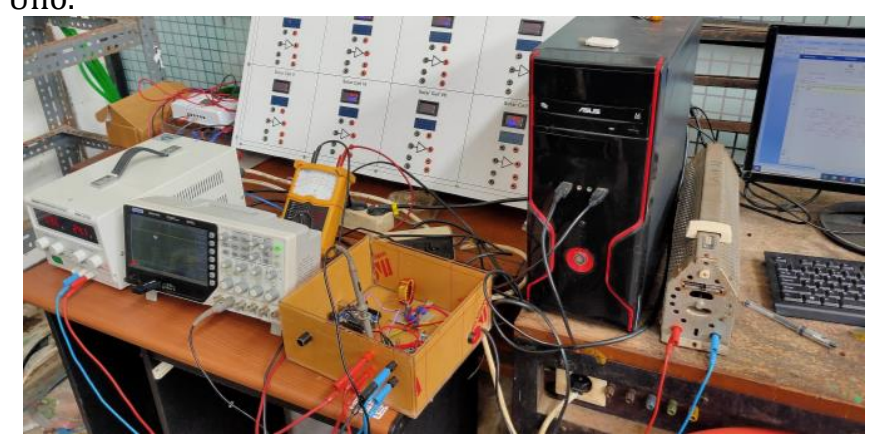

Gambar 6. Rangakain pengujian alat

Seperti yang terlihat pada gambar 6, Dalam pengujian konverter buck ini dibutuhkan beberapa peralatan pendukung diantaranya yaitu osiloscope digital, power supply digital, resistor geser sebagai dummy load dan sebuah PC yang dilengkapi software simulink matlab yang akan digunakan untuk memprogram arduino.

\section{Pengujian Tegangan input}

Konverter buck yang dirancang dalam penelitian ini diuji dengan tegangan input 24 Volt yang diambil dari power supply digital, seperti yang ditunjukkan dalam Gambar 6. Pengujian tegangan input dilakukan untuk memastikan tegangan yang keluar dari power supply sudah sama dengan tegangan input yang diingikan untuk input alat ini.

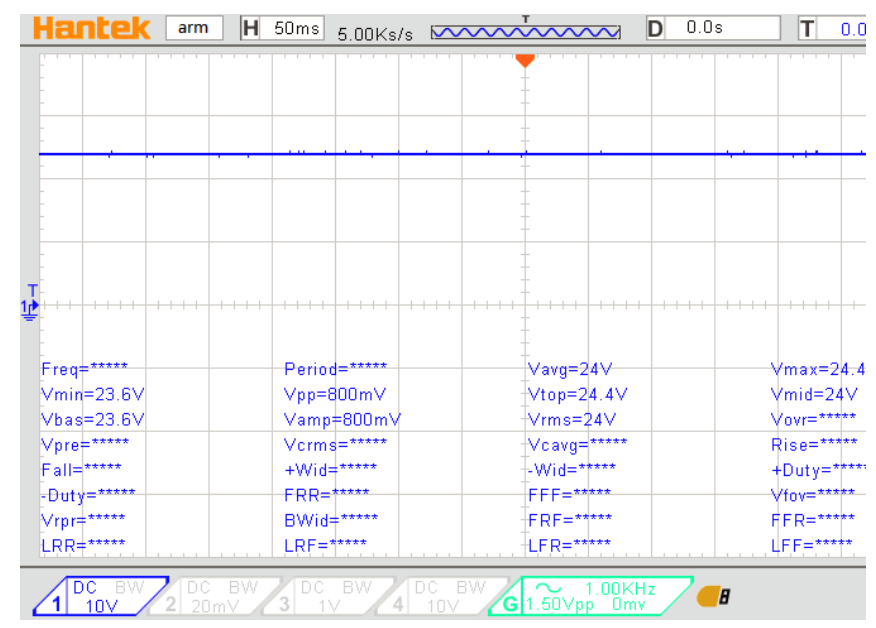

Gambar 7. Tegangan input konveter buck

Gambar 7 menunjukan grafik tegangan input konverter buck yang di plot menggunakan osiloskop digital dengan skala $10 \mathrm{~V} /$ div, terlihat tegangan input konverter buck yang terbaca oleh osiloskop adalah 24 volt.

\section{Pengujian Software}

Konveter buck diuji dengan tegangan output referensi sesuai dengan tegangan yang digunakan pada umumnya, yaitu 6 Volt, 12 Volt, 15 Volt dan 18 Volt. Tegangan output referensi ini diterapkan melalui potensiometer yang terhubung dengan port analog input mikrokontroler Arduino uno. Gambar 8 menunjukan tampilan program konverter buck yang dibuat dalam simulink Matlab dengan sebuah feedback dari sensor tegangan.

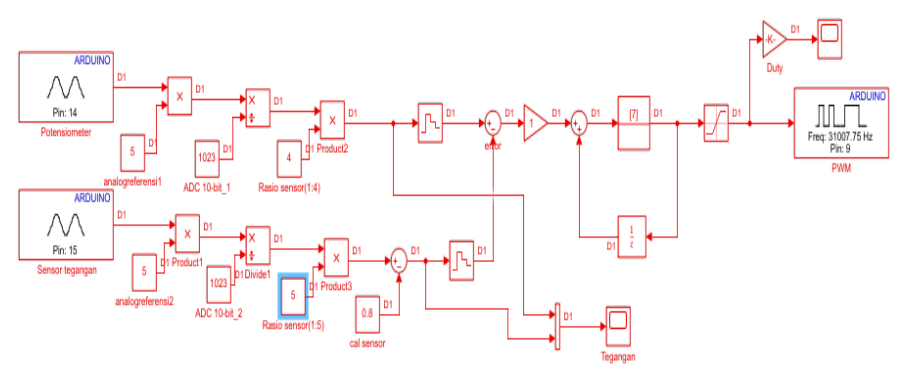

Gambar 8. Program konverter buck dalam simulink Matlab 
Dapat terlihat pada program yang di buat dalam simulink Matlab, terdapat 2 buah blok analog input dimana analog input tersebut masing- masing terhubung dengan sebuah potensiometer dan sebuah sensor tegangan pada pin Analog Arduino. Selanjutnya sebuah blok PWM digunakan untuk membangkitkan pulsa PWM pada pin 9 mikrokontroler Arduino uno. Gambar 9 menunjukan grafik tegangan output referensi dengan nilai 12 volt dan grafik tegangan output yang terbaca oleh sensor tegangan.

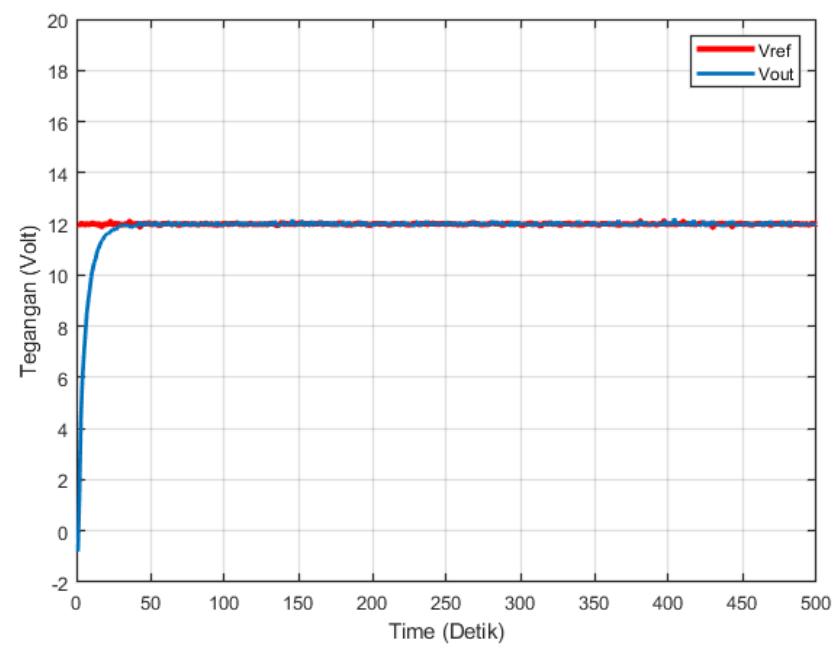

Gambar 9. Grafik tegangan output referensi dan tegangan output yang terbaca sensor

Gambar 9 menunjukan bahwa tegangan output yang terbaca oleh sensor sesuai dengan tegangan output referensi yang di set menggunakan potensiometer. Berikutnya merupakan bentuk gelombang PWM yang dihasilkan oleh pin 9 arduino uno.

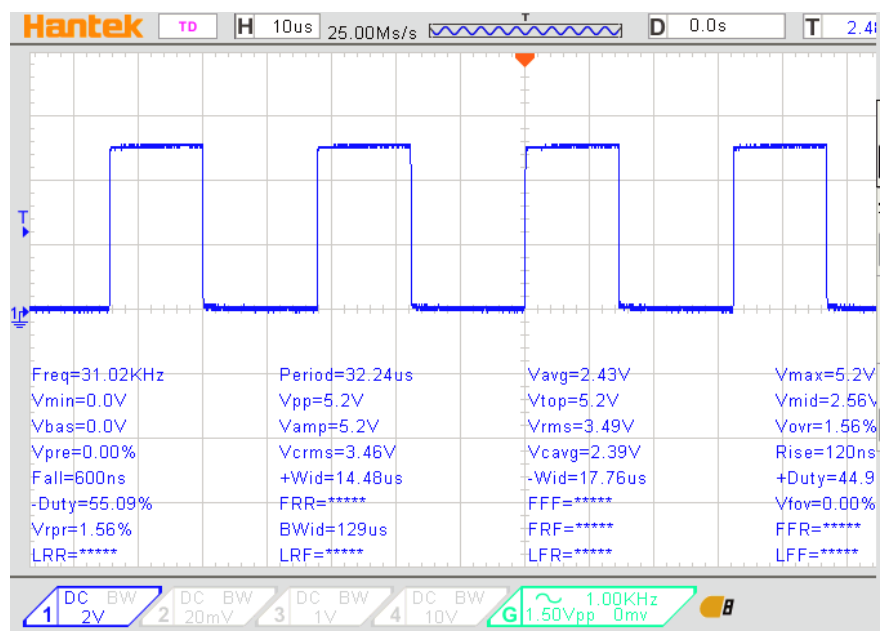

Gambar 10. Grafik gelombang PWM untuk tegangan 12 volt

Pulsa PWM yang dihasilkan pin PWM Arduino seperti ditunjukan oleh Gambar 10 diatas telah sukses menghasilkan tegangan ouput sebesar 12.2 Volt. Nilai tersebut sudah mendekati tegangan output referensi sebesar 12 volt yang di set oleh potensiometer. Gambar 11 menunjukan tegangan output konverter buck yang diukur mengguanakan osiloskop digital dengan skala grafik 10 volt/div. tegangan output konverter yang terbaca oleh osiloscope adalah 12.2 volt.

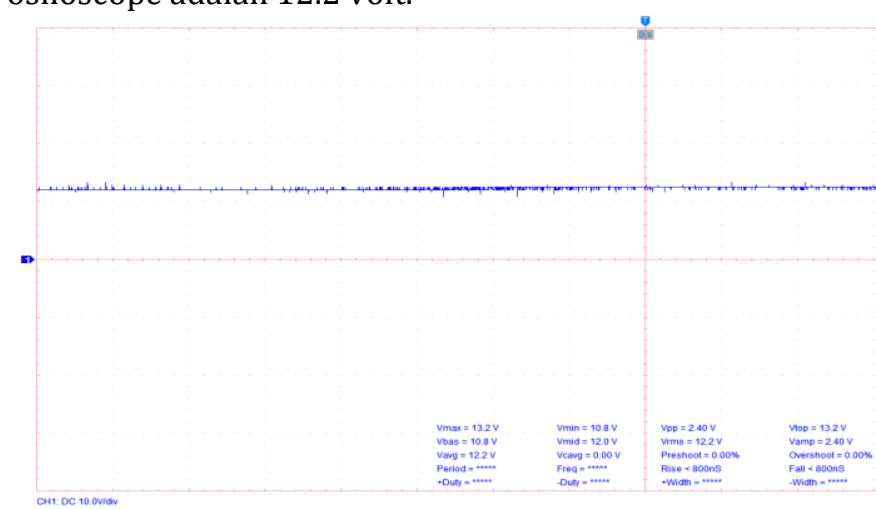

Gambar 11. Tegangan ouput konverter buck dengan set tegangan referensi 12 volt.

Berdasarkan hasil pengujian ini terlihat bahwa tegangan output konverter telah sesuai dengan tegangan output referensi. Kondisi tersebut menunjukan bahwa konverter buck yang dibuat dalam penelitian ini telah bekerja dengan baik sesuai dengan perencanaan. Hasil yang serupa juga didapatkan pada pengujian lainya dengan tegangan output referensi yang berbeda. Tabel 1 menunjukan ringkasan hasil pengujian konverter buck yang dibuat.

TABEL 1. HASIL PENGUJIAN

\begin{tabular}{|c|c|c|c|}
\hline \multirow{2}{*}{ NO } & \multicolumn{2}{|c|}{ Tegangan Output (Volt) } & $\begin{array}{c}\text { Duty cycle } \\
(\%)\end{array}$ \\
\cline { 2 - 3 } & Referensi & Pengukuran & 26 \\
\hline 1 & 6 & 6.1 & 51 \\
\hline 2 & 12 & 12.2 & 60 \\
\hline 3 & 15 & 15 & 80 \\
\hline 4 & 18 & 17.8 & \\
\hline
\end{tabular}

Hasil pengujian konverter buck yang diperlihatkan dalam Tabel 1 menunjukan bahwa konverter buck yang dibuat telah beroperasi dengan baik, dimana tegangan output yang diperoleh sudah mendekati atau sama dengan tegangan output referensi yang diinginkan. Hasil pengujian menunjukan bahwa error maksimum output hanya 0.2 Volt yakni saat pengujian dengan tegangan output referensi 18 volt dan 12 volt. Hasil pengujian dalam Tabel 1 ini juga menunjukan bahwa duty cycle PWM berbanding lurus dengan tegangan output referensi. Hal ini sesuai dengan hubungan tegangan output konverter buck dengan duty cycle yang diuraikan persamaan (1). Semua hasil ini menunjukan bahwa konverter buck yang dibuat telah beroperasi dengan baik dan dapat menghasilkan tegangan output sesuai tegangan referensi. 


\section{PENUTUP}

Berdasarkan dari pengujian yang dilakukan maka dapat disimpulkan bahwa sistem kendali konverter buck pada arduino yang diprogram menggunakan simulink Matlab telah bekerja dengan baik, dimana hal tersebut dapat dilihat dari tegangan keluaran konverter buck yang dihasilkan sudah mendekati atau sama dengan tegangan yang di setting meggunakan potensiometer. Besarnya duty cycle PWM pada rangkaian konverter buck mempengaruhi tegangan keluaran artinya nilai duty cycle PWM berbanding lurus dengan tegangan output referensi. Koverter buck yang dibuat ini hanya menghasilkan error maksimum tegangan output sebesar 0.2 volt. Penelitian ini dapat dikembangkan dengan menerapkan kendali yang lebih baik sehingga dapat digunakan pada beban yang berbeda-beda.

\section{REFERENSI}

[1] Aswardi, M. Yuhendri dan DTP. Yanto, Teknik Elektronika Daya, Indonesia : IRDH Book Publisher, 2020.

[2] Rashid, Muhammad H. 2011. "Power Electronics Handbook Third Edition". Elsevier's Science and Technology Department. Oxford. UK.

[3] Pramudifta. Andana, "Perancangan PWM Digital Konverter Boost Menggunakan Mikrokontroler Atmega8535",Universitas Negeri Padang, Padang, 2018.

[4] Dwi. Harselina, "Perancangan Boost Konverter", Universitas Negeri Padang, Padang, 2018.

[5] Peeyush and V. Chaurasia, "Design and Implementation of Boost Converter for IoT Application," Int. Journal of Innovative Research in Science, Engineering and Technology (IJIRSET), vol. 6, no. 6, June 2017.

[6] M. Cucuzzella, R. Lazzari, S. Trip, S. Rosti, C. Sandroni and A. Ferrara, "Sliding mode voltage control of boost converters in DC microgrids," Control Engineering Practice, vol. 73, pp. 161-170, April 2018.

[7] V. Viswanatha and R.V.S. Reddy, "Digital Control of Buck Converter Using Arduino Microcontroller For Low Power Applications", 2017 International Conference On Smart Technologies For Smart Nation (SmartTechCon), pp. 439-443,17-19 Aug 2017

[8] Enang Edovidata, Hafelzandan Aswardi. "Perancangan Sistem Pengisian Accumulator Motor Listrik dengan Sumber Listri Solar Cell Berbasis Mikrokontroler". JTEV (Jurnal Teknik Elektro Dan Vokasional). (hal 57-68). Padang : Teknik Elektro FT Universitas Negeri Padang.

[9] M. I. Esario and M. Yuhendri, "Kendali Kecepatan Motor DC Menggunakan DC Chopper Satu Kuadran Berbasis Kontroller PI," JTEV, vol. 06, no. 01, pp. 296$305,2020$.

[10] H. Matalata and L. W. Johar, "Analisa Buck Converter Dan Boost Converter Pada Perubahan Duty Cycle
Pwm Dengan Membandingkan Frekuensi PWM 1, 7 Khz DAN 3, 3 Khz," J. Ilm. Univ. Batanghari Jambi, vol. 18 , no. 1, pp. 42-50, 2018

[11] A. S. Werulkar and P.S. Kulkarni. "Design of Constant Current Solar Charge Controller with Microcontroller Based Soft Switching Buck Converter for Solar Home Lighting System", 2012 IEEE International Conference on Power Electronics, Drives and Energy Systems(PEDES 2012), Dec 16-19,2012.

[12] W. W. A. Ramadhan and T. Abuzairi. "Simulation and Analysis of a Buck Converter Based on an Arduino PWM Signal Using a Single Cell Li-Ion Load", 2019 IEEE International Conference on Quality in Research (QIR): International Symposium on Electrical and Computer Engineering, 20-23 june 2019.

[13] H. Kovacevic and Z. Stojanovic, "Buck converter controlled by Arduino Uno", 2016 39th Int. Conv. Inf. Commun. Technol. Electron. Microelectron. MIPRO 2016-Proc., pp. 1638-1642, 2016

[14] A. Aswaldi and M. Yuhendri, "Sitem Kendali Dan Monitoring Boost Converter Berbasis GUI (Graphical User Interface) Matlab Menggunakan Arduino", JTEIN, vol. 1, no 2, pp.266-272, 2020.

[15] Aswardi. 2010. Modul Elektronika Daya. Padang : Teknik Elektro Universitas Negeri Padang., No Title.

\section{Biodata Penulis}

Ari Anggawan, lahir di Jakarta, 12 Agustus 1994 Menyelesaikan Sarjana Terapan di bidang Teknik Elektro Industri pada Jurusan Teknik Elektro FT UNP.

Muldi Yuhendri, dilahirkan di Agam pada tanggal 13 Desember 1981. Menyelesaikan program Sarjana di jurusan teknik elektro Universitas Negeri Padang pada tahun 2005 dan Program S2 di ITS Surabaya pada tahun 2009 serta S3 Ilmu Teknik Elektro pada tahun 2017 di kampus yang sama. Bekerja sebagai staf pengajar di jurusan teknik elektro Universitas Negeri Padang sejak tahun 2006 sampai sekarang, 